\title{
Hyponatremia, Cardiac Tamponade and Carcinoembryonic Antigen in Lung Adenocarcinoma
}

\author{
Akciğer Adenokarsinomunda Hiponatremi, Kardiyak Tamponad ve \\ Karsinoembriyonik Antijen
}

Didar Şenocak, Tezcan Kaya, Kubilay İşsever, Ensar Özmen

\begin{abstract}
Cardiac tamponade and severe hyponatremia are life-threatening and significant clinical findings. Severe hyponatremia, carcinoembryonic antigen (CEA) levels above $1000 \mathrm{ng} / \mathrm{mL}$ and cardiac tamponade are rare conditions as initial findings of non-small cell lung cancer. We report a 60-year-old man who presented with a cough, shortness of breath, nausea and loss of weight. The CEA level of the patient was 1041 $\mathrm{ng} / \mathrm{mL}$. He also had severe hyponatremia and cardiac tamponade. The patient was diagnosed with metastatic lung adenocarcinoma following an evaluation. The patient underwent chemotherapy treatment, but died 4 months after the cancer diagnosis. Severe hyponatremia, very high levels of CEA, and cardiac tamponade as initial findings of lung adenocarcinoma may be predictors of higher stage disease and poor prognosis.
\end{abstract}

Key words: Carcinoembryonic antigen, cardiac tamponade, hyponatremia, adenocancer.

\section{Özet}

Kardiyak tamponad ve ciddi hiponatremi hayatı tehdit edebilen önemli klinik bulgulardır. Küçük hücreli dışı akciğer kanserinin başlangıç bulgularının ciddi hiponatremi, 1000 ng/mL'nin üzerinde karsinoembriyonik antijen (CEA) düzeyi ve kardiyak tamponad olması nadirdir. Bu makalede, öksürük, nefes darlığı, bulantı ve kilo kaybı şikayetleriyle başvuran 60 yaşında bir erkek hastayı sunduk. Hastanın CEA değeri 1041 $\mathrm{ng} / \mathrm{mL}$ idi. Aynı zamanda hastada ciddi hiponatremi ve kardiyak tamponad vardı. Araştırma sonucu metastatik akciğer adenokarsinomu tanısı konuldu. Hastaya kemoterapi verildi ve kanser tanısından 4 ay sonra eksitus oldu. Akciğer adenokarsinomunun başlangıç bulgularının ciddi hiponatremi, çok yüksek CEA düzeyi ve kardiyak tamponad olması ileri evre hastalık ve kötü prognoz göstergesi olabilir.

Anahtar Sözcükler: Karsinoembriyonik antijen, kardiyak tamponad, hiponatremi, adenokanser.
Department of Internal Medicine, Sakarya University Faculty of Medicine, Sakarya, Turkey
Sakarya Üniversirtesi Tıp Fakültesi, i̇ç Hastalıkları Anabilim Dalı, Sakarya

Submitted (Başvuru tarihi): 22.06.2019 Accepted (Kabul tarihi): 16.09.2019

Correspondence (iletişim): Tezcan Kaya, Department of Internal Medicine, Sakarya University Faculty of Medicine, Sakarya, Turkey

e-mail: kayatezcan@msn.com 
Lung cancer is one of the most frequently diagnosed malign diseases all over the world and ranks in first place among the causes of cancer death (1). Local symptoms caused by the primary tumor, symptoms caused by metastases or nonspecific symptoms are usually seen at the time of a lung cancer diagnosis. In a small group of nonsmall cell lung cancer (NSCLC) hypercalcemia, syndrome of inappropriate antidiuretic hormone (SIADH) secretion and Cushing's syndrome may be the initial findings of the disease (2). Some tumor markers, such as carcinoembryonic antigen (CEA), may be found to be elevated in lung adenocarcinoma patients. The serum CEA level is reported to be linked with the diagnosis, stage and prognosis of cancer (3). Severe hyponatremia, carcinoembryonic antigen (CEA) levels in excess of 1000, and cardiac tamponade, as initial findings of non-small cell lung cancer, is a very rare condition. We present a case in which all three findings were observed at the same time.

\section{CASE}

A 60-year-old male patient presented with a cough, shortness of breath, nausea and loss of weight to the emergency department of our hospital. He had no remarkable medical history or drug use, and had a smoking history of 20 pack years. Upon physical examination, the patient had distant heart sounds with no murmur or rhythmic tachycardia, and respiratory sounds were normal. Blood pressure was 100/60 $\mathrm{mm} \mathrm{Hg}$ and pulse rate was $125 / \mathrm{min}$. There was no sign of apparent edema or hypovolemia. In the lab tests, hemoglobin was $11.5 \mathrm{~g} / \mathrm{dl}$, MCV $83.5 \mathrm{fl}$, CRP $11 \mathrm{mg} / \mathrm{l}$ (0-5), sodium $114 \mathrm{mmol} / \mathrm{L}$ (136-146), potassium $3.8 \mathrm{mmol} / \mathrm{L}$, glucose $126 \mathrm{mg} / \mathrm{dl}$, urea $21 \mathrm{mg} / \mathrm{dl}$ (17-43) and creatinine $0.5 \mathrm{mg} / \mathrm{dl}(0.6$ 1.1). The patient was hospitalized in the internal medicine clinic for severe hyponatremia. Spot urinary sodium was $60 \mathrm{mmol} / \mathrm{L}$, urine osmolality was $432 \mathrm{mOsm} / \mathrm{kg}$, serum sodium was $114 \mathrm{mmol} / \mathrm{L}$ and serum osmolality was 231 $\mathrm{mOsm} / \mathrm{kg}$. The thyroid hormone parameters and cortisol levels were normal. SIADH was considered as the cause of hyponatremia. A hypertonic sodium solution was given intravenously, and fluid restriction was performed. The patient was evaluated for malign diseases. CEA level was found to be $1041 \mathrm{ng} / \mathrm{mL}$ (reference range 0-5). Gastroduodenoscopy and colonoscopy were normal. There was no pathological finding in an abdominal computed tomography (CT). A thorax CT revealed multiple lymphadenopathies (LAP) in the supraclavicular and left axillar regions (max. diameter was 14x10 mm). There were also lymph node conglomerate in all mediastinal regions and bilateral hilar, and a pericardial effusion with a maximum diameter of $1.5 \mathrm{~cm}$ (Figure 1). A bronchoscopy was performed, but there was no sign of a mass lesion. The cytology of the bronchoalveolar lavage fluid was found to be benign. A positron emission tomography-CT (PET-CT) revealed many malignant-looking LAPs in the mediastinum and cervical lymph nodes, with elevated FDG uptake in the paratracheal, aortopulmonary and hilar regions of the mediastinum (max. diameter was $2 \mathrm{~cm}$ ), while a hypermetabolic tissue lesion was noted in the right hemithorax hilar region that could not be distinguished from the lymph nodes. There were also malignant effusion images in both hemithoraces and in the pericardium (Figure 2). An excisional biopsy of the lymph node was made from the right supraclavicular region. At this point, the patient developed dyspnea, an increase in jugular venous pressure and a peripheral edema. A chest $X$-ray revealed an increase in the cardiothoracic ratio and water bottle sign (Figure 3). The patient had signs of cardiac tamponade, and an echocardiography revealed a pericardial effusion, $2.1 \mathrm{~cm}$ in diameter, in front of the right ventricle that led to signs of cardiac tamponade and diastolic collapse in the right ventricle. An immediate pericardiocentesis was performed by the cardiologist, and 3 liters of hemorrhagic fluid was drained. The cytology of the pericardial fluid was found to be malignant, compatible with the diagnosis of adenocarcinoma. A biopsy of the lymph node revealed a metastasis of a less differentiated lung adenocarcinoma. The patient's dyspnea regressed and his serum sodium level was stable at around $130 \mathrm{mmol} / \mathrm{L}$. As a result, a follow up of medical oncology was recommended and the patient was discharged. The patient was treated with chemotherapy during the medical oncology follow up, but the disease progressed and the patient died 4 months after the cancer diagnosis.

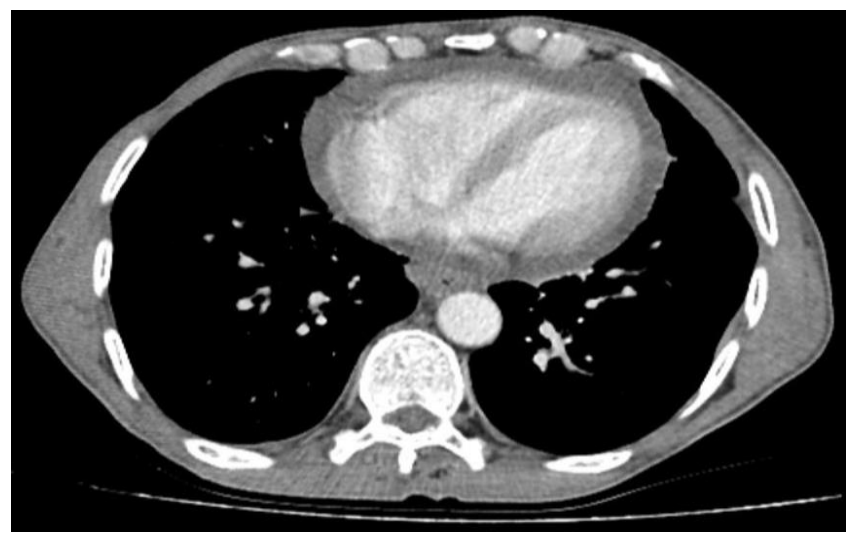

Figure 1: CT of the chest showing the pericardial effusion with a maximum diameter of $1.5 \mathrm{~cm}$ 


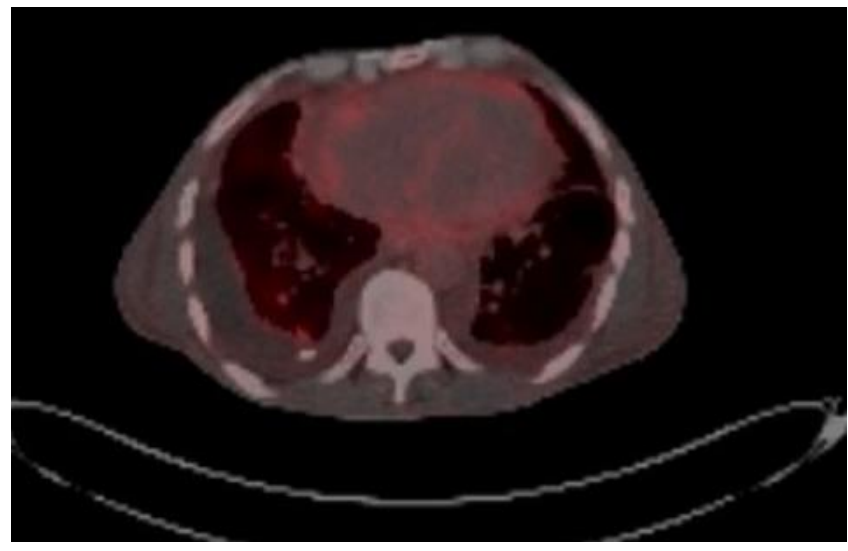

Figure 2: PET-CT revealed malignant effusion in both hemithoraces and the pericardium

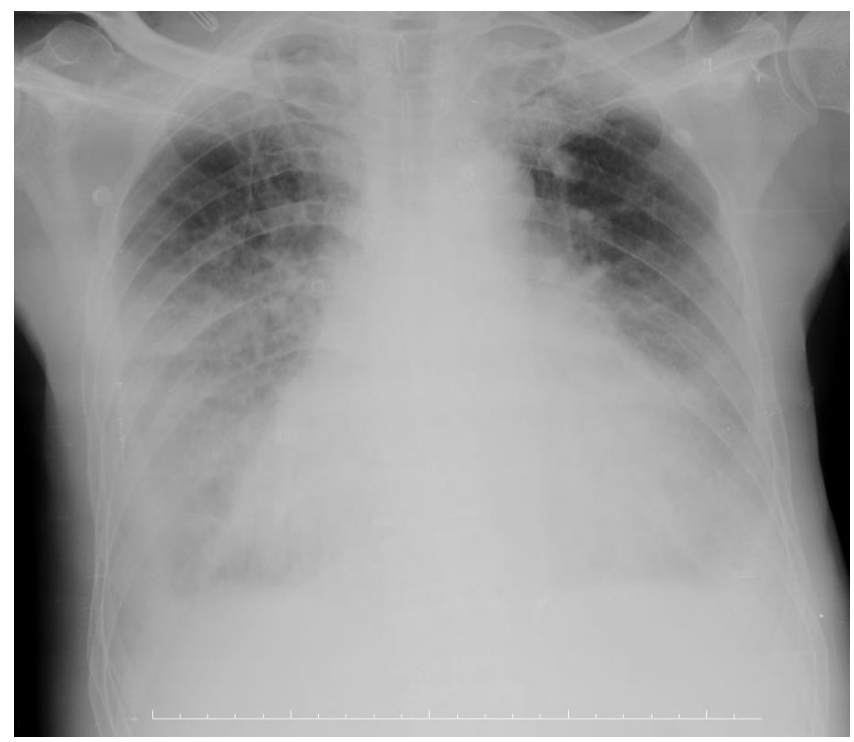

Figure 3: The radiograph of the chest revealed an increase in the cardiothoracic ratio and water bottle sign

\section{DISCUSSION}

Lung cancer is the leading cause of cancer death in the world (1). In lung cancer patients, the initial signs of a primary tumor can include chest pain, vena cava superior syndrome, dysphagia, hoarseness, dyspnea, cough and hemoptysis (2). Loss of appetite, fever, fatigue, weight loss and bone pain may also be seen as a result of the systemic effect of the cancer (2). In addition, paraneoplastic syndromes like SIADH, hypercalcemia, clubbing and polycythemia may be observed (2).

Hyponatremia is a dangerous electrolyte imbalance that can cause nausea, vomiting, fatigue, muscle cramps, convulsions, coma and death (4). A serum sodium level below $120 \mathrm{mEq} / \mathrm{L}$ is defined as severe hyponatremia, which is a life-threatening condition (4). The underlying cause of hyponatremia is usually SIADH in lung cancer patients $(4,5)$. This paraneoplastic syndrome is usually seen in patients with small-cell lung cancer (2). Severe hyponatremia, as an initial finding of NSCLC, is a rare condition that has been assessed in a few case reports (5). lyer et al. (5) reported on a patient with NSCLC who had hyponatremia at the level of $126 \mathrm{mEq} / \mathrm{L}$, secondary to SIADH, upon presentation. In their case report, brain metastasis was detected and chemotherapy-radiotherapy was started, and the patient lived for fewer than 2 months. In SIADH due to lung cancer, the treatment of the primary disease with surgery, chemotherapy or radiotherapy is recommended (4). Symptomatic cases with hyponatremia may be treated with intra-venous hypertonic sodium, fluid restriction or a vasopressin receptor antagonist (4). In the present study, the patient had severe hyponatremia, with a serum sodium level of $114 \mathrm{mEq} / \mathrm{L}$. Lung cancer presenting with hyponatremia has been linked to poor prognosis and higher stages of disease (5). The present case supports this, given that the patient survived for only 4 months.

Lung cancer rarely presents with cardiac tamponade as the initial finding $(6,7)$. The other common causes of tamponade are acute myocardial infarction, malignancy, infections, autoimmune disorders or surgery, or can be idiopathic (7). In addition to lung cancer, breast cancer, lymphoma, melanoma, mesothelioma and renal cancers are also reported among the malignant causes of tamponade (6).

Kumar A. et al. (8) reported on a 63-year-old woman who presented with signs of cardiac tamponade. An emergency pericardiocentesis was performed and the pericardial fluid cytology revealed metastatic adenocarcinoma of the lung. The survival of the patient was reported 7 months after the diagnosis of malignancy. Cardiac tamponade causes the fluid in the pericardial cavity to block the right heart filling, and leads to a reduction in cardiac output. Hypotension, tachycardia and increased jugular venous pressure can also occur in the presence of cardiac tamponade (7), and this condition may result in death unless urgent intervention is performed. If clinical tamponade is present, pericardial drainage must be carried out as soon as possible. The case in the present study developed cardiac tamponade, and pericardiocentesis was performed immediately. The pericardial fluid cytology indicated an adenocarcinoma metastasis. Pericardiectomy, percutaneous balloon cardiotomy, the creation of a pleuropericardial window, chemotherapy and radiotherapy are the other choices of treatment for tamponade (7).

Nowadays, tumor markers are often used for tumor staging, for the monitoring of treatment response and for the 
detection of recurrences. CEA is a tumor marker that is produced by tumor cells, and that may also increase in lung adenocarcinoma (9). That said, CEA does not increase in all lung adenocarcinoma patients, and serum levels above $1000 \mathrm{ng} / \mathrm{ml}$ are rarely seen (9). In a study of 158 lung adenocarcinoma cases, the mean serum CEA level was reported to be $1.88 \mathrm{ng} / \mathrm{mL}$ and the CEA level was found to be high in $28.5 \%$ of the patients (10). This study concluded that the follow-up CEA level can be a useful for the detection of early recurrence of lung adenocarcinoma (10). CEA serum level has been reported to be an important prognostic indicator in other studies involving NSCLC patients (3). High levels of serum CEA have been found to be associated with more the aggressive biological properties of the tumor, the quantity of tumor cells and higher stages of the disease, as an indicator of poor prognosis (3).

\section{CONCLUSIONS}

We present here a case with cardiac tamponade, severe hyponatremia and a very high level of serum CEA as the first indication of lung adenocarcinoma. It should be kept in mind that the etiology may be lung cancer in patients presenting with these rare findings. Hyponatremia secondary to SIADH, and very high serum CEA levels are rarely associated with NSCLC. The present case suggests that the coexistence of these three clinical features may point to metastatic disease, a high tumor burden and poor prognosis.

\section{CONFLICTS OF INTEREST}

None declared.

\section{AUTHOR CONTRIBUTIONS}

Concept - D.Ş., T.K., K.I., E.Ö.; Planning and Design D.Ş., T.K., K.I., E.Ö.; Supervision - D.Ş., T.K., K.I., E.Ö.; Funding - D.S.; Materials - D.S.,, T.K.; Data Collection and/or Processing - D.S.., E.Ö.; Analysis and/or Interpretation - D.S.., T.K.; Literature Review - D.S., T.K., K.I.; Writing - D.S.., T.K. Critical Review - T.K.

\section{YAZAR KATKILARI}

Fikir - D.Ş., T.K., K.I., E.Ö.; Tasarım ve Dizayn - D.Ş., T.K., K.I., E.Ö.; Denetleme - D.S.., T.K., K.I., E.Ö.; Kay- naklar - D.S.; Malzemeler - D.S.., T.K.; Veri Toplama ve/veya İşleme - D.Ş., E.Ö.; Analiz ve/veya Yorum - D.Ş., T.K.; Literatür Taraması - D.S.., T.K., K.I.; Yazıyı Yazan D.Ş., T.K.; Eleştirel Inceleme - T.K.

\section{REFERENCES}

1. Barta JA, Powell CA, Wisnivesky JP. Global epidemiology of lung cancer. Ann Glob Health 2019; 85:1-16. [CrossRef]

2. Spiro SG, Gould MK, Colice GL; American College of Chest Physicians. Initial evaluation of the patient with lung cancer: symptoms, signs, laboratory tests, and paraneoplastic syndromes: ACCP evidenced-based clinical practice guidelines. (2nd edition) Chest 2007; 132(3 Suppl): 149S-60S. [CrossRef]

3. Grunnet M, Sorensen JB. Carcinoembryonic antigen (CEA) as tumor marker in lung cancer. Lung Cancer 2012; 76:138-43. [CrossRef]

4. Peri A, Grohé C, Berardi R, Runkle I. SIADH: differential diagnosis and clinical management. Endocrine 2017; 55:311-9. [CrossRef]

5. Iyer P, Ibrahim M, Siddiqui W, Dirweesh A. Syndrome of inappropriate secretion of anti-diuretic hormone (SIADH) as an initial presenting sign of non small cell lung cancer-case report and literature review. Respir Med Case Rep 2017; 22:164-7. [CrossRef]

6. Burazor I, Imazio M, Markel G, Adler Y. Malignant pericardial effusion. Cardiology 2013; 124:224-32. [CrossRef]

7. Hoit BD. Pericardial effusion and cardiac tamponade in the new millennium. Curr Cardiol Rep 2017; 19:57. [CrossRef]

8. Kumar A, Puttanna A. Recurrent cardiac tamponade: an initial presentation of lung adenocarcinoma. BMJ Case Rep 2014; 21. pii: bcr2013202553. [CrossRef]

9. Molina R, Holdenrieder S, Auge JM, Schalhorn A, Hatz R, Stieber P. Diagnostic relevance of circulating biomarkers in patients with lung cancer. Cancer Biomark 2010; 6:163-78. [CrossRef]

10. Kim JJ, Hyun K, Park JK, Moon SW. The Significance of serum carcinoembryonic antigen in lung adenocarcinoma. Korean J Thorac Cardiovasc Surg 2015; 48:335-44 [CrossRef] 